\title{
Democratic Transits and Their Influence on the Election Laws in Russia
}

\author{
Arkadiy V. Shemelin ${ }^{1}$ \\ ${ }^{1}$ Transbaikal State University, Chita, Russia \\ Correspondence: Arkadiy V. Shemelin, Transbaikal State University, Chita, Russia. Tel: 7-924-377-2828. E-mail: \\ shemelin75@yandex.ru
}

Received: June 26, 2014

Accepted: October 7, 2014 Online Published: November 15, 2014

doi:10.5539/res.v6n4p58

URL: http://dx.doi.org/10.5539/res.v6n4p58

\begin{abstract}
The represented article is devoted to the analysis of peculiarities of embodiment of democratic transits into the legal field of the Russian state and their effect on election legislation in Russia. As a result it was concluded that for Russia namely in the context of election legal relations the effect of democratic principles has great value that is reduced to the following one: approval of internationally accepted values in the state sphere of Russia, increase of the responsibility level both of state and personality, wide distribution of justice principles that as a result will lead to the increase of population trust to the state system apparatus with simultaneous quality increase of officials' work. At the attention is paid to that the modern democracy in Russia bears formal character, it doesn't express and can't express interests of the population majority, as it happens in the conditions of western democracy. In this connection the basic task in the part of indirect embodiment of democracy principles in the election legal relations is the development of mechanisms of their implementation, which were already developed and are valid in the foreign countries.
\end{abstract}

Keywords: elections, state apparatus, democratic transits, legislation, state responsibility, legal field, justice principles, Russia, modern democracy

\section{Introduction}

Being the form of direct democracy, elections condition the implementation of the principles of legal nationhood in the system of state authorities' formation. In connection to this the electoral legislation must ensure their conduction with maximal transparency and honesty. The bases of democratization of electoral processes in the last decades formed in the world practice are actively embodied in the electoral legal relations with Russia. However, it should be noted that in spite of the enough proper regulation of election conduction procedure and the presence of attempts of their conformity to the democratic principles, the final goal has not been achieved yet that reduce the level of citizens' trust to the authorities formed in electoral ways. In connection to above-specified study of the effect of democratic transits on the electoral legislation of the Russian Federation acquires the special actuality.

The aim of the represented study is conduction of analysis of content, formation and general tendencies of effect of democratic transits on the electoral legislation in Russia.

\section{Material Studied}

For achievement of the specified aim on the basis of usage of different methods of scientific knowledge, namely, dialectic, comparative-legal, historical methods and etc. enough big quantity of the scientific studies in the area of political science, sociology, jurisprudence, which study leads to the conclusion of high level of scientists' interests to the specified problematic, was analyzed. In particular, such scientists as G. Almond, R. Dal', F. Zakarij, G. O’ Donnell, R. Inkhart, T. Karl, T. Karozers, Kh. Lints, S. M. Lipset, A. Pshevorskij, G. Rowen, A. Y. Melville, A. Stepan, S. Khantington, F. Shmitter and etc. devoted their works to the issues of study of essence of "democratic transits", their reasons and preconditions. Except for this, such scientists devoted their works to the problems of formation of the electoral right and legislation, including in the comparative-legal aspects as A. R. Akruchin, N. A. Alimova, Z. Sh. Bashev, S. V. Bolshakov, V. Z. Izmailov, S. M. Kremenetskii, S. D. Kniazev, E. V. Korchigo, P. A. Kucherenko, A. S. Kuchin, S. V. Lobachev, V. I. Lysenko, M. S. Matejkovich, L. Y. Makhashev, V. D. Mostovshchikov, A. P. Miasnikov, A. E. Postnikov, M. A. Pshenichnov, V. B. Sergeichuk, I. V. 
Sovetnikov, D. M. Khudolei, S. V. Yusov, A. A. Veshniakov, O. I. Gordeev, A. V. Ivanchenko, A. I. Kovler, V. I. Lysenko, A. P. Pankrukhin, V. E. Chirkin etc.

At that it should be noted that the insufficient study of the issues of democratic transits through the prism of electoral right of Russia in the legal area that also confirms the necessity of the corresponding study.

It should be marked that the electoral right and electoral process are directly connected with the political area of state and civil society functioning. The electoral right regulates the political right of the citizens to choose and be chosen, and the electoral process connected with models of electoral behavior shows the dynamics of participation of the citizens in execution of power. The electoral right and electoral process in aggregate forms the political-normative basis, which opens functioning of the institutes of electoral democracy.

At that it should be emphasized that the most important conditions of formation and development of the electoral right and process of RF is the formed transit of democratic Western-European values and international electoral standards, under which influence to the end of 1920 in the norms of electoral right of RF the right for freedom of opinion, word, information and free voting was fixed. The temporary marker of these changes is the stage of "post-founding elections" 1996-1999, when the stabilization of the electoral right is observed: actual recording in the norms of right of the democratic beginnings, including the basic provisions of international electoral standards not only on the federal, but on the regional levels too.

In its turn, according to view of R. Dal' the russian election laws have been formed in the period of democracy establishment, i.e. transit of western democratic institutions and values adjusted to the conditions of political realities of Russia in the beginning of 1990s years. Establishment of the "equality logic" in new political conditions (Dahl, 2000) entailed formation of concepts and approaches to the understanding of the ways for development of election laws in Russia, which would correspond to the goals and tasks formed by democratic institutions, and establishment of plebiscitary election system.

As the scientists note, the horizons of research interests concerning modernization processes entailed the following conclusion: "The process of modernization can paradoxically strengthen the value orientations of non-modernized type" (Rueschemeyer, 1985). The processes of radical changes have become of transformation nature, without blurring political and social traditions, which enabled deep and impartial evaluation of the problems of transition period. Democratization of the Russian society was associated with transitary processes in the entire political and social life.

As A.Y. Melville states "the democratic transit" (from lat. transitus.- transition, passing through) is the notion, uniting many varieties of transition processes from one public and political state (one or another variety of non-democracy) to the other state according to the form, at that namely consolidated democracy not obligatorily (and even not frequently) serves as final point of transition (Melvil, 2008).

According to $\mathrm{S}$. Khantington, the democratic transit is the process of state-by-stage change of configuration and interaction character of the leading political subjects in the political field of state. Based upon the stated studies he separated three models of democratic transit: "transformation", "change" and "transposition", which are followed by consolidation of the new political regime (Huntington, 2003).

N.A. Nikonova has a little different view of understanding of the category of "democratic transit", who indicates that we should understand "democratic transit" in the political process the rapid and radical change of traditional and vector building of the new system of social-political values on the basis of generally accepted democratic criteria (regular conduction of free, competitive, and fair elections, selectivity of the basic authorities of the state power, implementation of the fundamental human rights and freedoms, legal state with law priority in all areas of society life). In the majority of cases the democratic transits bear interrupted character: formation of democracy is taken in turn with the periods of return to totalitarianism. The process of generation and formation of democracy is not universal. The transit countries can move by the democratic ways of development, step away of this way or be in the stagnation state. Consolidated democracy, appearance of the defect model of democracy or complete coming back to totalitarianism can become the final point of transit (Nikonova, 2014).

\section{Discussion}

As it is specified in the scientific sources, the usage of democratic transit was caused by a number of reasons, including the following ones:

- Special aspects of historical development, which has formed since the time of Peter I the ideology of "overtaking" development for the purpose of eliminating the retardation of Russia from the West in the political and economic areas 
- Multinationality and polyethnicity of the Russian state

- The practice of political construction of a free society at the initiative of the ruling elite, actually without participation of people, established in Russia

- Legal nihilism time-honoured in the consciousness of people.

At that the transit strategy democratic with the progress resources was associated with establishment of western values, including the following ones:

- Representative democracy arising through the public election laws

- Liberalization of Russian society - establishment and implementation of such human rights as free speech, equal political and economic rights for all people; establishment of secularism, actual freedom of religion, strengthening of moral and ethic standards

- Individualism as an opportunity for personality development

- Market economy, competition, protection of private ownership rights

- Formation of local government

- Establishment of the principles of rule-of-law state

- Implementation of mutual freedom and responsibility of citizens and ruling elite for the state of matters in the country in the political life

- Expansion of forms and mechanisms of citizens' participation in the political life.

Russian state of the period of 1990s suffered internal conflicts, which reflected the political life and were the source of self-development. At the same time, they carried destructive potential: democratic construction was carried out without due regard to the objective state of the Russian society, distracting attention of the ruling elite and weakening the sovereignty. Instability of social, political and economic position in the country affected the vision of end and functional priorities, which determined stability of political situation and strength of the country.

In conditions of growing economic crisis the specific features of formation of a new political system, establishment of a rule-of-law state on conditions of establishment of democracy principles, creation of liberal basics of economy and availability of conservative forces have become a condition for choosing a future model of constitutional democracy.

In the researchers' view, on first stage in the beginning of 1990s years, there was an active discussion of the possibility of direct "copying" or reproduction of institutions of the western society in Russia. Global transformations "include the elements of destruction and redistribution of territorial boundaries of political and economic power" (Held, Goldblatt, McGrew, \& Perraton, 2004). In the said conditions, the Russian state appeared to be actually not ready to the perception of Western democracy, without appropriate adjustment and consideration of its own political, historical and national traditions. The absence of comprehensive and thorough knowledge of the existing state of matters in the country, which would allow understanding the aspects of foreign legal practice, which could be particularly carried over to the Russian institutional environment, has become a well-known obstacle on the way of direct transit.

The scientists have singled out two models of such transition: the first, agreement-based one, which is based on agreement of the forces on recognizing basic values of the civil society and perspective objectives of the movement; the second one is connected with the overcoming of the breakup of political forces, which results in the victory of one of the parties. Elaboration of conceptual provisions of democratic transit was not conceived and considered by the political elite. "Finally, the agreement-based model of adopting the constitution again gave way to the model of legal continuity breakup. The culmination of the entire transient period was the constitutional crisis of 1993, which actually finished in octroyed constitution. The issue of its legitimacy became the central problem of future constitutional modernization, having caused hard opposition of the parliamentary and presidential power" (Medushevskiy, 2003). The period under consideration was characterized by the carryover of gravity from the American model to the European models of constitutionalism, as they provided for the necessary image of public administration with the strong presidential power.

In the difficult political and social conditions of 1990s, a determinant factor for creating the space for interactions between the society and the state were the factors of democratic transit. The specific features of Russian mentality affected the establishment of such political system, which used to correspond to the previous image of the structure of political hierarchy. Surreptitiously, it became obvious as early as in 1991-1993, when 
the growth of parliamentarism faced unreadiness of the executive power to agree to reduction of its own role. Opposition of the executive power to democratic institutions was explained by its historically strong role in the state matters. The scientists will point out that the victory of B. N. Yeltsin "actually documented the end of the Soviet-communist period of the Russian history, and entry of the country in a new-democratic - epoch. But in its sections concerning organization of power, we again find the aforesaid regularity: being the consequence and documented end of the conflict of institutions claiming the governmental monopoly, it used to overcome it not in the logic of compromise (refusal from the idea of monopoly itself), but through more sustainable establishment of the Russian political and cultural principle of indivisibility of the supreme state power" (Kliamkin, 2000).

As we can see, the democracy positions were established in conditions of the division of powers between the executive and legislative authority, initiated process of autonomy of local government system, and, which is important, a whole chain of installation of electoral practices. The latter fully matches the model of "competitive elitism" by J. Schumpeter (1995), which actually does not exclude the model of "pluralism" by R. Dahl, which is based on two measurements of democracy - competitiveness of its actors and mass participation.

Being involved in the political and social transit, Russia will appear in conditions of high conflictogenity, when entropy may be manifested through intolerance to other people's opinion, up to their physical destruction. High risk, including polyethnicity, which was a "nutritive medium for ideologies and movements that may stand in the way of democracy, threaten peace, and generate ethnic conflicts in certain conditions" (Stanovcic, 1997), resulted in formation of a "broken society" that got out of the rule of traditionalism, but did not find its way to turning into the society of liberal values yet (Akhiezer, 1995).

In conditions of division by levels and branches of public authority, the frames of political participation got expanded. As election laws in their functioning entail electoral communication required to consolidate the unity of the civil society, the attention of the ruling elite will be paid to the electorate and election technologies. Democratic preferences of the political elite were generally supported by likes of Russian voters. The ruling elite in its aspirations appealed to the "rational voter", who considered the costs and advantages of the programs of different parties, and then voted for the party based on the principle of maximum benefit. It also used to appeal to "thoughtful voter", who consumes available political information without trying to verify it, which minimizes the costs, as the idea of democracy being the process of changing governments penetrates the voter' $\mathrm{s}$ mind (Huntington, 2003).

Democratic paradigm of Russian society and state development was actually a mainstream (primary direction) in the 1990s years spent in special conditions of Russian political technologies, including those in the election laws, which established the mechanisms of political participation of citizens in the administration of state matters.

The year 1993 in the Russian history was a turning year, and a transit from a preliminary phase to a decision-making phase. It is in this period that political legal standards of the society with their orientation towards polyarchal democracy have been established (Rustow, 1996). The choice of democracy model was made at the background of the denial of Marx and Engels's doctrine of democracy, which was based on the transformation of the society through the total political action. As A. S. Madatov believes, consideration of polyarchy as the procedural and processual democracy carries a number of restrictions related to the understanding of the fact that "in the theory of democracy the final consensus on the supreme values and goals of democratic development will never be achieved, no matter whether they are freedom, social and economic equality, economic fairness etc." (Madatov, 1999).

At that it should be noted that we understand polyarchy (the term was introduced by R. Dal' in 1953) or polyarchyc democracy (ancient Greek $\pi 0 \lambda v \alpha \rho \chi i \alpha$-"polycracy, power of many") as political system, based upon the open political competition of different groups in the fight for voters' support (Dahl, 2010).

The principles of polyarchy required from Russia in the newest conditions considerable deconcentration of economic and political resources. According to the concept of R. Dahl, the election plays the most important role in the evaluation of political regime, as it allows:

- Controlling the governmental decisions with the help of elections

- Enabling the citizens to express their opinion in a wide range of political problems in a free manner, without fear and without force, including criticism of public authorities, government, regime, social and economic system, and ruling ideology

- Realizing the citizens' right to strive for alternative sources of information, and moreover, such alternative sources really exist and are protected by laws

- Ensuring the existence and autonomy of independent associations and organizations, including political parties 
and groups by interests.

Realization of the idea of polyarchy activated discussions in the Russian society on the need to hold the Constituent Assembly as a democratic representative body (The Effectiveness of Political Parties' Actions in the Elective Campaign [EPPAEC], 1994). This idea matched the ideas of a special procedure for adopting the Constitution, and referendum was supposed to be held on the issue of the need to convene the Constituent Assembly. Therefore, it was offered to come back to some initial historical point - to the year 1917, in order to restore justice and legitimacy of the government. It was obvious that this idea was based on the ideas of "public agreement". Therewith, there was a historical example of adopting the US Declaration of Independence in 1776 by the Second Continental Congress, followed by adopting the Constitution of a new American State by the US Constitutional Convent. In 1789, the General States convened by the king of France proclaimed themselves the Constituent Assembly, thus laying the foundation for the republican form of governance. Further on, in 1791, 1793, 1795, 1848, 1875, and 1946 in France, in 1814 in Norway, in 1820 in Spain, in 1822 in Portugal, in 1831 in Belgium, in 1879 in Bulgaria and in a number of other countries their constitutions were adopted by constituent assemblies. Establishment of the actual right of the nation to change their own constitution was taken as a basis for future ideas of the guarantees of political freedoms and constituent right of the nation. The RF Constitution (art. 135) has been somewhat affected by the ideas of the Constituent Assembly, where the law-maker assigns revision of provisions of chapters 1,2 and 9 of the Constitution of Russia to the competence of the Constitutional Assembly convened particularly for this purpose. Alongside with that, the issue of the possibility of social contract and consistency in the implementation of initial institutional choice remained unsolved.

In 1993-1995, the search of the consistent model of graduate, well-protected, partially transient approach towards the development of the institutions of democratization and market economy became up-to-date (Carothers, 2000). The main emphasis was made on reformation of election laws aimed at regulation of parties' activity and changing the mechanism of electing the deputies of the State Duma. The election laws as a political value were associated with the notions of ethic control over the observed communication.

Therefore, we can state that the institutional leap in the formation of new concepts of a rule-of-law state has taken place after 1993. Adoption of the Constitution of the Russian Federation updated a previous type of legitimation of political institutions, which required respective development in a symbolic sphere of basic concepts of legitimacy of social and political procedure and break-off with the previous period of political and legal history.

Studying the democratic transit in the modern Russia, political experts indicate on the range of difficulties in its execution, connected with the absence of sufficient preconditions for its successful execution, among which are the weakness of civil society, absence of real pluralism, political apathy of population, sharp property polarization of population, combined with the small quantitative presentation of the middle class in the social society structure. The negative effect on the political transformation is made by such phenomena as the continuing economic crisis, interethnic conflicts and regional separatism. Among other reasons of instability of democratic transit in Russia, we should note the surficial mastering of the valuable and procedural aspects of democracy by all subjects, participating in the democratic process (by society, state, political elites, parties).

Orientation for the democratic ideal is definitely the most preferred from among all basic political orientations. Yet, one should take into account that the democratic ideal should also be matched with the context of social life of our country, become a reply to specific questions put by its historical development, represent the application of political structures of other countries to realities of a specific country.

The aggravated understanding that the processes going on in Russia have their own reading showed itself apparently in the process of colloquium "Modern Social Concept: Liberal View", which took place in 1994, and a number of dilemmas was put. The first of them concerned studying the issue of "resuscitation" of pre-revolutionary liberalism of emigrants defending the ideas of classical liberalism due to Russian intellectual tradition, in the spirit of values of spiritual roots of the nation, state, individual rights and freedom. The second dilemma concerned development of so-called "humanitarian ideological aid" from the West and implementation of liberalism in Russian only through the market. The third dilemma concerned the understanding of the synthesis of liberalism and democracy in the Russian conditions, and finding how whether it was possible to talk about inventing something new, matching the present Russian conditions (The Possibilities of Liberalism in the Interpretation of Modern World [PLIMW], 1994).

Among the scientists there exist opinions on the impossibility of implementing the ideas and values of western liberalism in Russia because of a great number of reasons. In particular, G. Rosmoser specified that "if liberalism 
has any future in Russia, it would have to get along together with enlightened conservatism" [Rosmoser, 1993].

Alternative reasoning was connected with the possible union of liberal clerisy and reformists with the competitive and non-nomenclative middle class: "Liberal reformists cannot realize their political potential in nomenclative conditions, when appointments and decisions are made, and political struggle is carried out "under the carpet", based not on the law and democratic will of the nation, but on personal relations, hidden agreements, backstage traditions, lobbying and bribery" (Ulyukayev, 1995).

It should be taken into account that the disputes of liberal values were held at the background of contradictions between the goals of market economy, intensified social differentiation, and impossibility to secure state social liabilities in the previous volumes.

The period of 1994-1995 was full of discussions related to holding the second parliamentary election. As said by V. Ya. Gelman, political disputes of that time mainly concerned the problems related to the choice of election systems. The disputes concerned several problems. In one case, the principal discussion between the followers of proportional and majority electoral formulas continued. In the other case, in conditions of new democracies a famous thesis of J. Sartori that "the election system is the most specific instrument of political manipulations" was subject to re-thinking. Finally, the problem of election system formation as a social choice was also in the agenda for further studies (Gelman, Golosov, \& Meleshkina, 2000).

Another important reasoning was about the specific features of Russian realities: "At first, the choice of the election system was not connected with the choice of other elements of institutional design, especially with the model of division of authorities. At second, the choice of election system took place in two stages: the stage of preliminary choice (1993), and the stage of establishment and institutionalization of the election system (1994-1995). At third, through the primary choice of the election system was actually imposed by the supporters of Yeltsin after the takeover of 1993, establishment of the election system was the result of consensus of political actors" (Gelman, Golosov, \& Meleshkina, 2000).

It is specific that the reasoning that the common election law loses its importance, and is substituted by public opinion appears at about the same time. It is what a famous French politician and political scientist M. Rocard wrote about in the very beginning of 1990s, while emphasizing the role of mass media: "To a certain extent public opinion will substitute class struggle in the role of the driving force of history, speeding up or braking down activity of the society" (Rocard, 1990). At the level of public conscience, such reasoning got the outline of a thesis about mass media being the "fourth authority".

"The RF Constitution of 1993 by a number of its parameters was ahead of its time. That is why the most important problem of the next constitutional reforms was to overcome the growing tension of the norm and reality. It was clear that in conditions of law nihilism, apathy, and serious opposition, constitutional norms can be brought into action only from the top-down" (Medushevskiy, 2003).

At the public level, the mechanisms of searching for ideological concepts related to the understanding of integrity of the Russian state were involved at that time, which was reflected in the Address of the President to the Federal Assembly with the specific title "On the consolidation of the Russian state" (APRF, 1994). Among politicians, at the level of political rhetoric, the theory of "new Russian nation" was introduced. Therewith, the country's top leadership did not exclude retention of adherence to the principles of democracy and corresponding procedures. In conditions of crisis, such consistency had positive result, facilitating the understanding of importance of natural and inalienable human rights possessed from the very birth by the society. However, as mentioned by N. I. Matuzov, realization of these rights was limited at that time. The supreme ideals did not coincide with hard reality, and democratic transformation was only expected to be filled with real content in accordance with the Declaration of Rights and Freedoms and the Constitution of the Russian Federation (Matuzov, 1994).

Therefore, the concept of "vertical democracy" by the American political scientist J. Sartory was of great interest. He believed that political controlling groups exercise their power towards most of the socium in accordance with their position. At that in his opinion, the top of the power-wielding pyramid is occupied by the most dignified people who have merits to the society. The mechanism of "choosing, selecting" such people fits in the system of "selective polyarchy", and, therefore, in the democratic procedures of election (Solovyev, 2001).

We can assume that further evolution of political regime in Russian has coincided with this concept in a certain sense. It should be taken into account that this model reflects stable types of political organization, while in transient periods a formal criterion of selecting the top leaders reserves its traditional forms of supremacy, which are typical for the model of "ministerial state" or authoritarian systems. In such conditions "the state suffers 
continuous impact of tension between sovereignty and controllability, which have become rather two poles of its activity than two phases of its history: it has been reflected in creation of the striking force and establishment of minimal survival income. The combination of microphysics of authorities, through which the life is controlled in its smallest manifestations, and totalization, due to which the power of the state is organized in competition with other states, and which finds its culmination in war, breeds a never-ending issue of legitimacy of the state" (Colas, 2001).

The difficulties with direct transit of developed form of western democracy resulted in appearance of different theories, from "delegative democracy" by G. O' Donnell, "new democracies" by F. S. Weffort, to "facade democracy" and "defective democracy" by V. Mercel and A. Croissant.

In 1996-1999, the counter processes going on in the structure of political institutions and society emerged full blown in conditions of active support of structures and groups facilitating the civil society development by the West. But in these conditions, the topic of counter processes related to establishment of authoritarism and its relapses became subject to discussion.

The reason of that was concealed in the evaluation of a type of political regime established in Russia and containing important peculiarities. They were the following:

- The absence of parliamentary control over the government and its possible removal through the vote of nonconfidence

- The absence of appropriate system of restraints: absence of exclusive prerogative of the lower chamber for law-giving activity, and assignment of the functions of the head of executive authority to the president

- The absence of strict constitutional division of authorities, and wider interpretation of the rule by decree, which is far from being limited to emergencies.

In fact, the Russian President combines the status of the president in the presidential republic and the prime minister. "Changes in the relations of the president, the parliament, and the government in modern conditions are primarily connected with the developing tendency towards creation of hybrid and mixed forms of governance and territorial and political division" (Chirkin, 2000).

The issue of socialization of citizens in new conditions remained unsolved. The influence of these discussions affected the need to revise legal approach towards studying the election laws in the context of its three main aspects - as an object of management by the society, as a self-governing system, and as a forming and regulating mechanism of power-wielding relations. The understanding of usefulness of a new approach towards understanding the role and importance of election laws in the political life of the country got its prevalence, as a "basic idea of law as a legal condition and procedure for achievement of justice, freedom and order does not fully match the ongoing changes.

In relation to electoral legislation, then, as the scientists mark, modeling of its norms involves reflection of the electoral behaviour, that serves as a system of connection that unites the society with the renewed ideas of justice, as "the history of establishment and development of democratic norms and practices says that democracy is a process, a process of development, expansion and update of ideas and principles, institutions and procedures" (Melvil, 1999).

At that we can agree with Panasyuk I.P. in relation to that the basic tendencies of improvement of the electoral system of modern Russian society as a factor of its transformation are the following ones: a) possibility of transition from the mixed system (majoritarian-proportional) of elections to the system of proportional representative office; b) formation change mechanism of the representative bodies of the state power of RF subjects and the system of formation of the representative bodies of the local self-government; c) attempts of the most large political forces of modern Russia to set electoral system bases, which conform to their political ambitions more; d) improvement of electoral technology mechanism, which gives advantages for enhancement of the electoral activity of population; e) attempts of creation of "protest" voting population blocking mechanism ("against all"), in particular, by means of removal of this variant of voting in the vote bulletin; f) further growth of role and meaning of electoral system as a factor, effecting on the development of modern Russia (Panasyuk, 2004).

At that as the scientist states in the process of electrical campaign the citizens, having the electoral right, political parties and their blocks can become not only the subjects, but the objects of electoral process, when in their relation the electoral agitation-propagandistic campaign, directed on formation of the relation to the aims and programs of certain candidates, political parties and their blocks. 
The peculiarity of Russian electoral system is that in opposition to many other states, in the Constitution of Russian Federation there is special section about the electoral right (electoral system). Only in the most general form the active and passive electoral rights are fixed in art. 32 of the Constitution of Russian Federation, and also in the art. 31 at determination of the order of elections of the Russian Federation President. Meanwhile, the fixation of the electoral right principles is applied to the elections in all state authorities of the country and local self-government in the Constitution could do transformation possibilities of RF electoral system more fundamental and ensured.

Any right-minded actions should definitely not impose the non-proportional burden on the society. Public recognition in this period is of spontaneous nature, and the competition in the political area is treated as negative contrariness. We can find the analogue in the field of economics and in the evaluation of privatization results, when the public conscience has got a vicious circle of poor legitimacy of owners' rights and related flaws of corporate management represented by the state (Yavlinskiy, 2003).

The situation with the rating of the processes of public life was of threatening nature, when the oligarchs started directly influencing the approval of political decisions, thus creating in the voters' conscience a feeling of "privatization of politics".

Against this background the discussions on the "democracy of participation", which according to the idea of R. Dahl corresponded to the democratic process got special importance, that was:

- Active (effective) participation: all members of the community have equal and effective opportunities to express their views in the process of elaborating the decisions concerning public matters

- Equal voting: all members of the community have equal and effective opportunities to vote in the process of decision-making

- Understanding based on awareness: every member of the community receives information to understand the heart of the questions the decision is made on

- Control over the agendas: members of the community influence the decision-making with regard to the questions to be discussed and voted for, and the order of their discussion and voting. This excludes control of any executive body over the circle of questions to be discussed, and the policy of the community always remains open for changes

- Including adults: all full-age and capable citizens are able to participate in elections; in order to protect its own interests, a group of citizens cannot delegate another group the power over itself without damage for itself. The experience shows that one can understand its interests in a non-adequate way, thinking that other people can act more reasonable than him. But delegating the power to other people, you lose the opportunity to act when you come to adequate understanding of your own welfare (Dahl, 2000). The criteria of R. Dahl differed from the constitutional, essential and procedural standards of democracy: "According to Dahl, most of standard democratic institutions - elective officers; free honest and regular elections; free expression of one' s opinion, freedom of speech; availability of alternative sources of information; independence of voluntary (or public) unions; wide-coverage democracy - can be analyzed and compared" (Tilly, 2007). The main problem here was that only minimum set of democratic institutions that did not concern time changes, and therefore were not connected with revelation of the degree of changes in the process of democratization, was described. Besides, each of the criteria applied to a limited extent only, and when exceeding these limits, they conflicted each other, just like it was with the freedom of speech and independence of associations (Tilly, 2007).

Therefore, "the democracy of participation" is possible only in the developed civil society, but the latter shows itself to the extent democracy is being realized (Yasin, 2005). This mechanism could be started only with the help of election laws, engaging the society in resolution of electoral disputes. The gravity was carried over to a legal plane. A driving reason for each reaction could be the understanding of a simple fact that it is through democratic elections that the public and administrative authorities responsible to the citizens are built up, and it is through participation in the election process that the public policy is being influenced. It is legitimate election that is the most effective and legally unconditional form of realization and protection of one's own economic and social interests (Vedeneyev \& Smirnov, 1997).

The laws on elections adopted in conditions of democratic transit (1995), i.e., Federal Laws "On the major guarantees of voting rights of the citizens of the Russian Federation", "On elections of deputies of the State Duma of the Federal Assembly of the Russian Federation" and others were far from being perfect. Their interpretation by the interested elite allowed open violation of the principle of justice, the existence of which is a priori immanent to law. According to Art. 77 of the Constitution of the Republic of Tatarstan, "any number of 
candidates can be included in the voting bulletins". This wording allowed recommendation of only one candidate to the elective position, which was used by the local political elite. The President of the Republic of Tatarstan M. Shaimiyev was elected on a non-alternative basis in 1991 and 1996, i.e. without competitors and honest competition. At the elections of 1995 to the State Council (the parliament of the Republic) over twenty heads of local administrations were also elected on a non-alternative basis (Farukshin, 1997).

A reverse side of the formally organized process were the issues related to simulation of political and legal forms, models, rules and procedures of participation of voters and their associations in the elections. In fact, they faced the simulation of external signs of structural transformation, which was called to retain and preserve the regime of non-political governance not substituted based on the results of elections. There was a wide opportunity for establishment of very undesirable modification of relations between the society and the state, which was the regime of anonymous democracy (Vedeneyev \& Smirnov, 1997).

Electoral technologies guaranteed inter alia in the election laws, political consulting for Russia of the transient period created the situation that resulted in the "crisis of participation", growth of political estrangement by one part of the electorate, and protest voting by the negatively spirited voters. Uncertainty in the understanding of political and legal values in the combination with absolutization of the role of the institutions of authorities reduced the influence of wide circles of the population on the government.

As we can see, "democracy acts as a specific "political project", which is implemented in already established conditions of a certain country. As for the degree of inner readiness of the country to establishment of democratic political regime, it is treated as an associated factor that can either speed up or brake down the formation of such systems" (Solovyev, 2001).

Summing up the foregoing, it should be mentioned that in spite of the reasoning on the impossibility to introduce in Russia the ideas and values of western liberalism, the Russian society underwent the process of democratization with regard to its particular realities. The abundance of political discussions in 1994-1995 was connected with the second parliamentary election, that is why the law-giving process in the said period paid major attention to reformation of election laws, which were of special political importance in the period under consideration. The constitutional norms of 1993 by a number of its parameters were ahead of their time. New regulatory acts of the elective laws were supposed to eliminate tension in the society, caused by numerous reasons, including specific features of a very unique political regime established in the country, which differed a lot from any other regime in the world, and evaluation of which caused discussions on the possibility of reverse processes connected with the establishment of authoritarism and its relapses.

Real influence on the political decision-making by oligarchs generated a feeling of "privatization of politics" in the voters' minds. In spite of attempts to reflect democratic ideology of the western type in the innovations of election laws, federal and regional election laws (1995) were far from being perfect, allowed manipulating the norms with inaccurate wording of the law-giver, and establishing the power of the persons willing to enter the "big politics".

The aforesaid finally invoked non-confidence by the citizens of the Russian Federation towards the election process, the elections were not treated as the main form and way of democratic struggle for the possession of public authority, and the form of participation in control over its implementation. Political estrangement of a part of the electorate and protest voting by the negatively spirited voters was observed. A kind of "theatricalization" of political life in conditions of low-level political institutionalization differs in its extreme cynicism, indifference of politicians to practical satisfaction of deep electoral interests of the citizens" (Zyryanov, 2007).

Russian citizens used to have their electoral behaviour formed on the basis of updated mental images and electoral culture. In fact, none of the versions discussed in the society will be implemented in its pure form. But western general democratic liberal value adjustable to the conditions of political realities in Russia have been established in Russia in the process of transit, having changed in a qualitative way the norms of election laws, psychology of Russian voter, which allows talking about a real transit of western democratic values in the society, state, and law, including election laws.

The issues of modification of the political regime in Russia made the society to come to a conclusion that the "failure of democracy in the forms it used to take at that time does not refute the need of democratization as such, and, which is most important, does not eliminate the need for democratic reflection" (Pantin, 2003).

\section{Acknowledgements}

Thus, the conducted analysis of democratic transits gives grounds to make more wide conclusions and consider advancement of democracy as the global project of transnational processes. For Russia namely in the context of 
electoral legal relations the effect of democratic principles have big meaning, which is reduced to approval of the worldly recognized values in the state sphere of Russia, increase of responsibility level both state and personality, wide distribution of the justice principles, that finally leads to trust enhancement to the system of state apparatus with simultaneous increase of officials' work quality. Moreover, the implementation of democracy principles will lead to recognition of the Russian Federation as a legal state that completely came aside from the authoritarianism and totalitarianism that will simplify the processes of cooperation with West countries.

At the same time it should be emphasized that today democratic principles found its embodiment in greater extent in the formalized aspect of electoral legislation. The practical state of affairs evidences that the democracy in Russia has the official character and it doesn't express and can't help to expressing the interests of the majority of population, as it happens in the western democracy conditions. In connection to this, the basic task on the part of direct and actual embodiment of democracy principles in the electoral legal relation is working-out of the mechanisms of their implementation, which are already developed and act in the foreign countries.

\section{References}

Akhiezer, A. S. (1995). Russia—Broken Society. Rubezhi, 5, 67-75.

Carothers, T. (2000). Aiding by the West the Establishment of Civil Society in the Eastern Europe and Former USSR. Constitutional Law: East-European Overview, 1(30), 2-9.

Chirkin, V. E. (2000). Reformation of the Russian Constitution: Milestones, Problems. Social Sciences and Modern Times, 5, 42-61.

Colas, D. (2001). Political Sociology. Moscow: Ves Mir.

Colloquium Overview. (1994). The Possibilities of Liberalism in the Interpretation of Modern World. Polis, 3, $125-130$

Dahl, R. (2000). About Democracy. Moscow: Aspekt-press.

Dahl, R. (2010). Polyarchy: Participation and Opposition. Moscow: GU WSE.

Farukshin, M. H. (1997). Federalism and Democracy: Difficult Balance. Polis, 6, 164-173.

Gelman, V. Y., Golosov, G. V., \& Meleshkina Y. Y. (2000). The First Electoral Cycle in Russia (1993-1996). Moscow: Ves Mir.

Hantington, S. (2003). The third wave. Democratization in the late twentieth century. Moscow: PROSSPEN.

Held, D., Goldblatt, D., McGrew, A., \& Perraton, J. (2004). Global Transformations. In Politics, Economics, and Culture (p. 33). Moscow: Praxis.

Huntington, S. (2003). The Third Wave. Democratization in the End of XX Century. Moscow: Russian Political Encyclopedia.

Kliamkin, I. M. (2000). Post-Soviet political System in Russia: Origins, Development and Perspective of Transformation. Acta Slavica Iponica, 17, 180-186.

Madatov, A. S. (1999). Democracy Concepts and Models: Problems and Dilemmas. The Bulletin of the People's Friendship University of Russia. The Politology Series, 1, 57.

Matuzov, N. I. (1994). Personality, Politics, Law. In Theory of Politics (General Issues) (pp. 28-29). Saratov: Publishing House of Saratov Institute of Law.

Medushevskiy, A. N. (2003). The Russian Constitution in the World Political Process: To the 10th Anniversary of RF Constitution of 1993. The World of Russia, XII(3), 62-103.

Melvil, A. Yu. (1999). Democratic Transits (Theoretical, Methodological and Applied Aspects). Moscow: MONF.

Melvil, A. Yu. (2008). Politics. Moscow: Prospect.

Nikonova, N. A. (2014). Democratic transition in the political process in Latin America: implementation features (Unpublished master's thesis). Transbaikal State University, Chita, Russia.

Panasyuk, I. P. (2004). Electoral system as a factor in the transformation of modern Russian society (Socio-philosophical analysis) (Unpublished master's thesis). Military university, Moscow, Russia.

Pantin I. K. (2003). Democracy in Russia: Contradictions and Problems. Polis, 1, 137-148.

Rocard, M. (1990). Putting Life in Work. Moscow: International Relations. 
Rosmoser, G. (1993). About the Future of Russia. The Issues of Philosophy, 4, 20-24.

Rueschemeyer, D. (1985). Quoted from: Criticism of Modernization Theory. Research and analytical overview. Moscow: Press.

Rustow, D. A. (1996). Transitions to Democracy. Towards a Dynamic Model. Polis, 5, 5-6.

Sartory, J. (1993). Vertical Democracy. Political Studies, 2, 80-89.

Schumpeter, J. (1995). Capitalism, Socialism, and Democracy. Moscow: Ekonomika.

Solovyev, A. I. (2001). Politology: Political Theory, Political Technologies. Moscow: Aspekt Press.

Stanovcic, V. (1997). Searching for New Designs: Alternatives to Federalism (the Yugoslavian Experience). In Paper Presented at the XYII World Congress of the International Political Science Association (Vol 2, 16-19). Seoul.

The Address of the President of the Russian Federation to the Federal Assembly. (1994). On the Consolidation of the Russian State (primary directions of domestic and foreign policy). Rossiyskaya gazeta, p. A3.

The Effectiveness of Political Parties' Actions in the Elective Campaign. (1994). Materials of the workshop on April 17-19 (pp.119-121). St. Petersburg: Khudozhestvennaya Literatura.

Tilly, Ch. (2007). Democracy. Moscow: Institute of Public Development. http://dx.doi.org/10.1017/CBO9780511804922

Ulyukayev, A. V. (1995). Liberalism and Politics of Transient Period in the Modern Russia. The World of Russia, $4(2), 22-25$.

Vedeneyev, Y. A., \& Smirnov, V. V. (1997). Representative Democracy and Electoral Legal Culture. Moscow: Ves Mir.

Yasin, E. (2005). Will Democracy Survive in Russia? Moscow: Novoye Izdatelstvo.

Yavlinskiy, G. A. (2003). Peripheral Capitalism. The Lectures on the Economic System of Russia at the Turn of XX-XXI centuries. Moscow: EPIcenter.

Zyryanov, S. G. (2007). Electoral Behavior in Conditions of Genesis of Democratic Institutions. Socium and Public Authority, 4, 39-43.

\section{Copyrights}

Copyright for this article is retained by the author(s), with first publication rights granted to the journal.

This is an open-access article distributed under the terms and conditions of the Creative Commons Attribution license (http://creativecommons.org/licenses/by/3.0/). 